length, by $\frac{3}{4}$ in breadth, pure white ground. The spots are more bold, larger, and of a brighter reddish colour than those of S. Ludoviciana, and are diffused over the whole surface, instead of being crowded toward the larger end, as is the case in the common species. The irides are brownish, and the hairs on the upper eye-lid longer and more numerous. The general colours and markings are much the same in both species, but much paler in the present one.

FAMILY VII.*-MUSCICAPIN ÆE. FLYCATCHERS.

Genus II.†-MUSCICAPA, Linn. FlyCATCHER.

\title{
YELLOW-BELLIED FLYCATCHER.
}

\section{Muscicapa flaviventris, Baird.}

PLATE CCCCLXL.-MaLe.

I am indebted to my young friend Spencer F. Baird, Esq. of Carlisle, Pennsylvania, for specimens of this new Flycatcher, which that gentleman and Wy. M. BaIrd, Esq. accurately described in Vol. I. of "The Proceedings of the Academy of Natural Sciences of Philadelphia," (July and August 1843 , Nos. 28,29, p. 283,) and from which I have made my figure. The following account of its habits, and also the description of its specific characters, are given by the two gentlemen above indicated.

"This species was first observed in the spring of 1840, near Carlisle, Pennsylvania. During every succeeding spring since, it has been seen in greater or less numbers, and several specimens procured each year. Its habits are much like those of the other species of this genus; it frequents low thickets near small streams, is seldom found in large woods like $T$. acadica, or $T$. virens, and is a very unsuspicious bird, allowing persons to approach within a short distance. It probably goes farther north than Pennsylvania to breed, having never been observed after the latter part of May or beginning of June."

* See vol. i. p. 195.

† Ibid.p. 198. 
Yellow-bellied Flycatcher, Tyrannula flaviventris, Baird.

5 inches 4 lines, 8 inches 8 lines.

Pennsylvania. Probably found in the Allegheny Mountains and Middle Districts.

Male.

"Body rather stout. Bill broad, and the sides convex. Tarsus longer than the middle toe. Wings rounded; third primary longest, fourth slightly shorter, second one line shorter than the third and two lines longer than the fifth, first shorter than the fifth, but longer than the sixth. Tail emarginate and slightly rounded.

"Bill above dark blackish-brown, beneath light yellowish-brown. Feet brownish-black. Plumage of the upper parts deep greenish-olive, crown of the head rather darker, the feathers having their centres dark brown. A narrow ring around the eye pale yellow. Lower tail coverts, abdomen, and linings of the wings, bright sulphur-yellow, deepest on the abdomen. Sides of the body, fore part of the breast, and sides of the neck, olive, lighter than the back, and inclining to yellowish on the throat. Primaries and tail feathers dark brown, the former bordered with greyish, and the latter with olive, like the back. The lower row of lesser wing coverts and the secondary coverts darker, tipped with pale yellow, that colour forming two bands across the wing. Secondaries darker than the primaries, and edged with pale yellow.

"Length 5 inches 4 lines; extent 8 inches 8 lines; folded wing 2 inches 9 lines.

"The sexes are similar in colour, but the female is generally rather smaller.

"Observations. This strongly marked species will at once be distinguished from every other by the deep yellow of its under parts. It resembles T. acadica of GMeLin (querula of WiLson) somewhat in form, but acadica by comparison will be found to be a larger bird, lighter olive above, and very pale yellow beneath. The tail of acadica is even or slightly rounded, in this species emarginate.

"We have no specimen of $T$. pusilla of Swarnson, but upon comparison with the description in Swainson and Richardson's "Zoology of North America," (so favourably known for accuracy,) it appears to differ in the colour of the upper parts, pusilla being "intermediate between hair-brown and oil-green;" our species is of a decided olive-green; the front of pusilla is "hoary;" in our species dark brownish-olive; the bands on the wing greyish-white; in our species pale yellow; "throat and breast" of T. pusilla "pale ash-grey;" in this species the throat is yellow, and the breast olive tinged with yellow." 


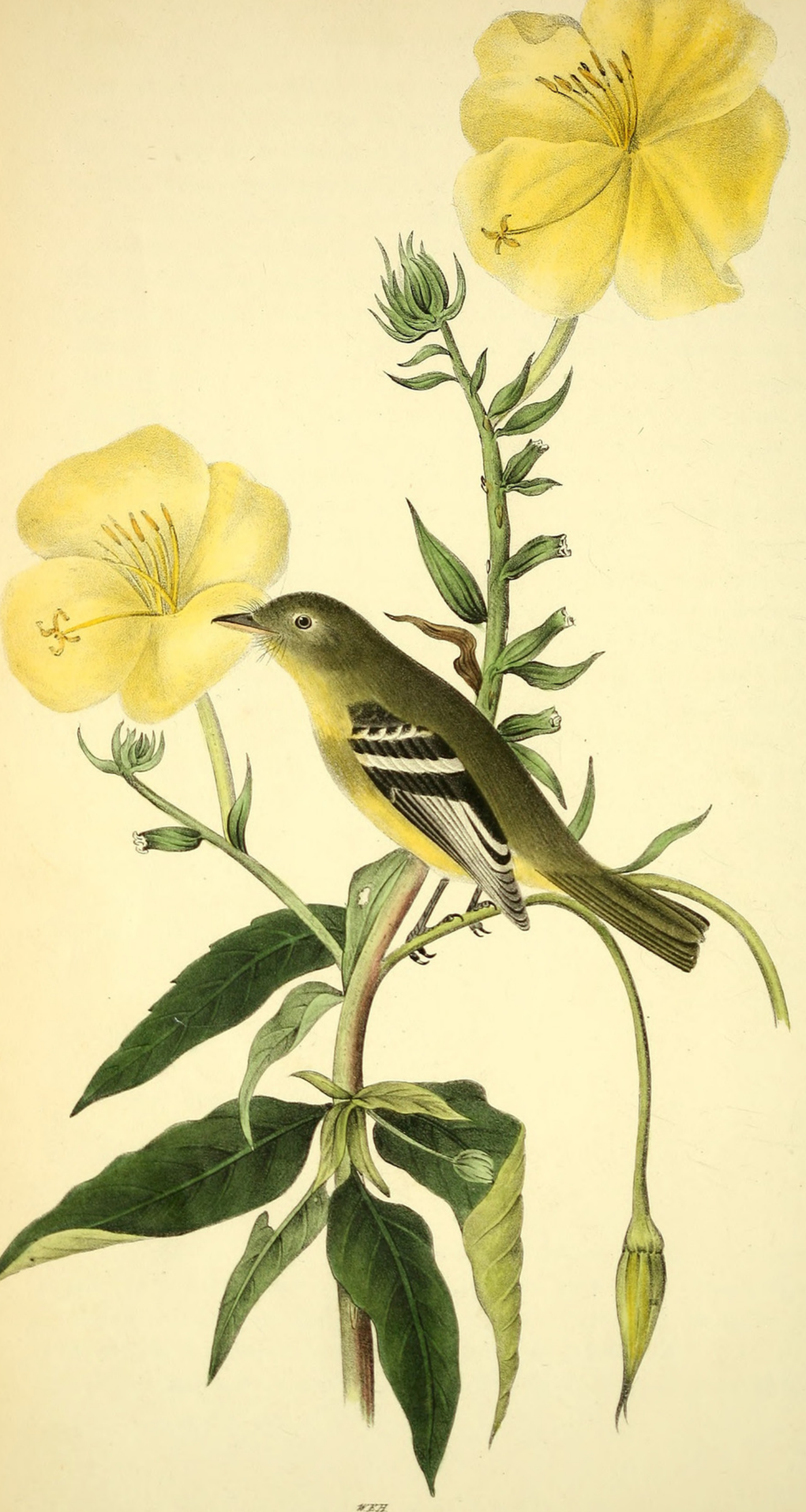

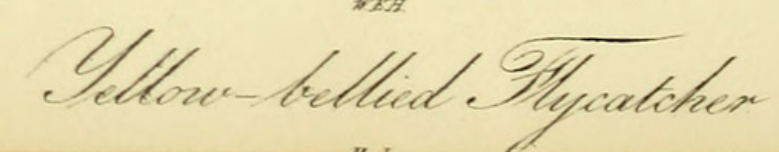




\section{$2 \mathrm{BHL}$ Biodiversity Heritage Library}

Audubon, John James. 1844. "Yellow-Bellied Flycatcher, Muscicapa flaviventris, Baird. [PI. 490]." The birds of America : from drawings made in the United States and their territories 7, 341-342. https://doi.org/10.5962/p.319607.

View This Item Online: https://www.biodiversitylibrary.org/item/124981

DOI: https://doi.org/10.5962/p.319607

Permalink: https://www.biodiversitylibrary.org/partpdf/319607

\section{Holding Institution}

Smithsonian Libraries

\section{Sponsored by}

Biodiversity Heritage Library

\section{Copyright \& Reuse}

Copyright Status: NOT_IN_COPYRIGHT

This document was created from content at the Biodiversity Heritage Library, the world's largest open access digital library for biodiversity literature and archives. Visit BHL at https://www.biodiversitylibrary.org. 